\section{TERTIARY ECDNDMY AND MANAGERIAL STUDY FIELDS AND ISSUES DF SCIENCE EDUCATION AIMED AT DATABASE SYSTEMS}

\author{
Ján Záhorec, \\ Alena Hašková, \\ Michal Munk, \\ Martin Bílek
}

\section{Introduction}

Quality of education is assessed on the background of the society`s needs and requirements. The particular aspects related to the term quality education are influenced by the most significant features or tendencies in the society at the time. In today's technology-based societies, understanding fundamental scientific concepts and theories and the ability to structure and solve scientific problems are more important than ever before. An understanding of science and technology is central to a young person's preparedness for life in modern society. This was reflected also in indicators on quality education selected by the working committee of national experts in 2000 (EC, 2001). Among the indicators included in the area of attainment, one can find mathematics, reading, science, information and communication technologies, foreign languages, the ability to learn to learn and civics. Reading skills play a central role in an individual's learning at school in all countries and also all countries share a solid grounding in mathematics at the very core of the educational curriculum. Scientific disciplines create bases for much of the core foundations of business and industry in each society. Information and communication technologies are having an accelerating impact on the way we learn, live, work, consume, express and entertain ourselves. The use of information and communication technologies is reflected also in one of the key competency, which should be developed within the formal school education (through informatics education), and it is the computer literacy of the students. This can be carried out either by particular curricular informatics subjects or across different subjects of non-informatics specialization.

In relation to science education informatics education has a special position. On the one hand, science education is perceived as education in mathematics, physics, chemistry and biology, but on the other hand, informatics together with technology is very often also incorporated into the content of this term. Already from 2000 the OECD's international study of education PISA (Programme for International Student Assessment) has assessed learn-
Abstract. Currently science education is understood not only as education in mathematics, physics and chemistry, but also as an education in informatics. To analyze the current state of informatics education within the tertiary economy and managerial study fields was the aim of the research, the purpose of which was to support curricula innovation in the relevant study programmes and to bring their content closer to the demands and needs of the labour market. An original feature of the research has been the fact that it has been based on students 'points of view. The research sample consisted of students of the concerned study programmes in the Slovak and Czech Republic. The paper presents methodology of the carried out questionnaire survey and main findings related to the data recorded at items focused on database systems and technologies. The obtained data related to the respondents 'opinions and the assessments of the selected learning topics taught within their study programmes and the importance of these topics for the respondents ' professional career were processed according to the factors of the country, gender and field of the study. The results showed a significant dependence of the respondents 'answers on their field of the study independently on their gender and the country in which they took their study. Key words: tertiary education, evaluation methodologies, curricula innovation, science education, scientific literacy, informatics, computer literacy.

Ján Záhorec

Methodology and Pedagogy Centre in Bratislava, Slovak Republic

Alena Hašková, Michal Munk

Constantine the Philosopher University in Nitra, Slovak Republic

Martin Bílek

University of Hradec Králové, Hradec Králové, Czech Republic 
ing achievements of 15-year-old students periodically in three-year cycles. PISA monitoring focuses on the youth`s ability to use their knowledge and skills acquired at schools to meet real-life challenges. While the first cycles of the OECD's international monitoring of education PISA (Programme for International Student Assessment) were focused mainly on the level of the 15-year-old students ' reading literacy, since 2006 the PISA monitoring has paid more and more attention to students' competency in mathematics and mainly science. Within that the orientation of the monitoring has been increasingly shifted to what students can do with what they learn at school and not merely with whether they have mastered the specific curricular content. In 2006, 2009 and consequently in 2015 a domain part of the PISA monitoring was scientific literacy (in 2012 the main domain of the PISA monitoring was the financial literacy of the youth (OECD, 2014). While, as it was already mentioned, the common understanding of science education reflects knowledge obtained in mathematics, physics, chemistry and biology, PISA defines scientific literacy as the ability to use scientific knowledge and processes, not only to understand the natural world, but also to participate in decisions that affect it (OECD, 2007a, 2007b, 2010a, 2010b, 2014). It defines it as an individual's scientific knowledge, and the use of that knowledge, to identify questions, acquire new knowledge, explain scientific phenomena and draw evidence based conclusions about science-related issues; their understanding of the characteristic features of science as a form of human knowledge and enquiry; their awareness of how science and technology shape our material, intellectual and cultural environments; and their willingness to engage in science-related issues, and with the ideas of science, as a reflective citizen (OECD, 2009). In the context of the PISA 2015 monitoring the view of scientific literacy, which forms the basis for this cycle of the international assessment of the youth education achievements, is a response to the question what is important for young people to know, value, and be able to do in situations involving science and technology (OECD, 2015).

\section{Problem of Research}

Nowadays, in Slovakia informatics is integrated in different forms in the study programmes of almost all study fields, carried out at the tertiary level of education. With the exception of technical faculties and departments of informatics offering study programmes directly in the field of informatics. Education in the field of informatics is mostly focused on applied informatics in the context of the particular study field and the profile of the graduate of the relevant study programme. An important reason, why informatics topics are included into the study programmes of the study fields economy and management on the tertiary level of education (ISCED 6, ISCED 7), is a need to develop students ' computer literacy in general (MŠ, http://www.akredkom.sk/index.pl?tmpl= odbory), and enhance those their informatics competencies, which have a broad transfer from the point of practice and labour market view (PAS, http://www.alianciapas.sk) and enhance one`s adaptability in personal out-of-service life (Skalka, Drlík \& Švec, 2012; Pešaković, Flogie \& Aberšek, 2014).

Proclaimed overall unsatisfactory level of informatics education within the economy and managerial study programmes considerably relates to the insufficient attention paid to the fitting of teaching database into the study programme curricula. Partially, it is also a consequence of a low lesson allocation devoted to subjects taught within the informatics education in the concerned study programmes (Lareki, Morentin \& Amenabar, 2010). Graduates of economy and managerial study programmes usually are not learned to be able to develop and program databases and information systems by themselves. But on the other hand, in practice the majority of them is facing situations in which they are asked to define and specify requests which a designed institutional information system should fulfil. Demands and requirements of practice show, that not only the employees in leading positions, but also the common users of the information systems, who daily entry and update the data in the systems, should be familiar with the basic principles on which these systems run and are operated (Lamanauskas, 2013, Burgerová, Maněnová, \& Adamkovičová, 2013).

\section{Research Focus}

A way how to eliminate the proclaimed dissatisfaction with informatics education offered by the higher education institutions to their students within the economy and managerial study programmes is to innovate and modernize the relevant curricula and to bring their content closer to the demands and needs of the labour market. But this has been done on a reasonable platform, not in an intuitive way. To create such a platform for a possible innovation of the informatics education leading to a higher professional competency of the graduates of the economy and managerial study fields, there was initiated a research which aim was to analyze the current 
state of informatics education within the relevant study programmes. An original feature of the research has been the fact that it has been based on students` points of view.

\section{Methodology of Research}

\section{General Background of Research}

Instruction of database systems and database technologies at Slovak and Czech higher education institutions is carried out dominantly by the faculties majoring in information and communication technologies (i.e., faculties of informatics, information technologies, electrical engineering, etc.). In some cases, instruction of database systems and database technologies is done, also at other faculties by their departments specialized in the field of informatics.

Database systems and database technologies are taught also within the majority of the economy and managerial study programmes, offered by the concerned faculties in Slovakia as well as in the Czech Republic. In comparison with the technical faculties, weight (credit value), lesson allocation (number of lessons devoted to informatics education) and arrangement of the appropriate subjects or courses (first or second level of the tertiary education, term of their instruction, their status of a compulsory or optional subject) they depend strongly on the particular study programme graduate`s profile (for example administration of the database systems is not taught at all faculties of economy and management and the same applies also to the development of database applications). These facts are consequently reflected in the particular subject or course curricula. The concerned one or two term courses (subjects incorporated into the study programmes) are usually drafted in a way, which enables students to acquire basic database knowledge and skills to program in the SQL database language on the user level or, if appropriate, to gain also some database modelling knowledge.

Very often a common factor of different discussions led at the professional forums is the importance of a higher education knowledge applicability to the practice (Zúbková \& Orosiová, 2011; Robbert, Wang, Guimaraes \& Myers, 2000; Šebo, 2013). We are witnesses of a rapid development of the database and information technologies. For this reason, it is very important to make the up-to-date trends in this field to be one of the key points within the informatics curricula incorporated into the economy and managerial study specializations at the tertiary level of education (Johnston \& Webber, 2003). Very often integration of these topics into the curricula of the particular informatics subjects taught at higher education institutions is not easy and immediately feasible. A consequence is that the graduates leave their alma maters with the knowledge which does not fulfil their employers` expectations on them (Jong, 2007).

Different research results show that currently provided instruction in the field of informatics related to the database issues incorporated in some economy and managerial study programmes of higher education institutions in Slovakia more or less does not respond to now-a-days needs of practice neither to now-a-days requirements of employers on the professional competencies of the graduates. Because of that, a question arises - how the instruction of database systems and database technologies within the economy and managerial study programmes should be modified (its scope, content, arrangement) to bring it in accordance with the current needs of the practice and constantly increasing informatization in all life areas. The carried research was to give at least some partial answers to this question.

Keeping in mind the above-mentioned facts, the carried out research analyzed the current state of the informatics education in the selected economy and managerial study programmes just from the point of view of the database systems and database technology instruction to modernize and optimize informatics teaching according to the needs of practice and requirements of the labour market on the competency profile of the relevant study programme graduates.

\section{Sample selection}

Considering the relationship between the systems of education in the Slovak and Czech Republic (their common development), the Czech Republic was chosen as a comparative country, the situation in Slovakia was compared with. The research samples in both these countries, the groups of the questionnaire respondents, were created primarily on the basis of availability of the students enrolled in the observed study programmes and secondarily on the basis of the selected study programme relevance as regards their specialization, their graduate 
profiles, number of students as well as their reputation. In Slovakia the research sample consisted of students of the Faculty of Economics and Management (FEM), Slovak University of Agriculture (SUA) in Nitra, enrolled in one of the following study programmes: Business Management (BMA), Quantitative Methods in Economics (QME), Accounting (AC), Agrarian Trade and Marketing (ATM) or Business Economics (BEC), and students of the Faculty of European Studies and Regional Development (FESRD), Slovak University of Agriculture (SUA) in Nitra, enrolled in the study programme European Development Programmes (EDP). Due to our limited possibilities, the research sample in the Czech Republic consisted only of the students attending the Faculty of Business and Economics (FBE), Mendel University (MU) in Brno, enrolled in study programmes Economic Policy and Administration (EPA) and Accounting and Taxes (ACT). All these faculties offer education in nearly identical study programmes of economy and managerial study specializations.

Composition of the research sample in dependence on the factors (in the meaning of the variables related to the respondent characteristics) COUNTRY, GENDER and FIELD OF STUDY (study specialization) is presented in Table 1. Herein, it is necessary to notice that COUNTRY means the country in which the respondents undergo their higher education studies and not the respondents' nationality.

Table 1. Composition of the research sample according to the respondent characteristics.

\begin{tabular}{clc}
\hline \multicolumn{2}{c}{ Factor (variable related to the respondent characteristics) } & N \\
\hline \multirow{2}{*}{ COUNTRY } & Slovakia (SK) & 493 \\
& Czech Republic (CZ) & 42 \\
\hline \multirow{2}{*}{ GENDER } & Female (F) & 373 \\
& Male (M) & 162 \\
\hline & Business Economics (BEC) & 319 \\
& Agrarian Trade and Marketing (ATM) & 62 \\
& Quantitative Methods in Economics (QME) & 28 \\
& Accounting (AC) & 37 \\
& Business Management (BMA) & 20 \\
& European Development Programmes (EDP) & 27 \\
& Accounting and Taxes (ACT) & 18 \\
& Economic Policy and Administration (EPA) & 24 \\
\hline
\end{tabular}

Using the above-mentioned research sample the research was aimed at four subtasks:

- mapping and analysis of informatics education with focus on the database systems and database technologies in the context of the selected economy and managerial study programmes carried out at the chosen faculties in the Slovak and Czech Republics,

- comparison analysis of the informatics education carried out in the Slovak and Czech Republics within the concerned study programmes done in focus on the database systems and database technologies instruction,

- recommendations to optimize informatics subject instruction within the analyzed study programmes in accordance with the current requirements on the observed study programmes graduates` knowledge and skills related to the database systems and database technologies,

- proposal and design of animation and simulation models in the context of innovation and modernization of informatics subject teaching in the frame of the concerned tertiary study programmes.

\section{Instrument and Procedures}

Mapping and analysis of the current state of informatics education in the concerned study programmes was based on the screening of the students' opinions by means of a questionnaire survey. The necessary research data were collected through a questionnaire, in the frame of which the respondents expressed their opinions and as- 
sessments of different actually taught or potentially innovated topics related to database systems and database technology issues. The fact that the research has been based on students` points of view can be evaluated as an original feature of the carried out research.

In the screening the students expressed their opinions and requirements or needs to insertion different relevant topics into the curricula of their study programmes from the point of view of their study specialization. The screening was based on the use of a questionnaire consisted of 104 items which were structured in six areas (questionnaire parts $\mathrm{A}-\mathrm{F}$ ):

- Part A: Introduction (7 items)

- Identification of the respondent's gender, age, study specialization

- Part B:What I want to learn (26 items)

- Identification of the informatics topics/subjects, which the students want to learn from those included in the actual curriculum of their study programmes, estimation of the level of attractiveness of these subjects for students (how interesting they are for students in the context of their further career specialization)

- Part C: My future profession (24 items)

- Estimation of the level to which some given factors are important for students in their decisions made at their future job selection

- Part D: What / would like to learn (22 items)

- Identification of the informatics topics/subjects which the students would like to learn and which are not included in the actual curriculum of their study programmes, estimation of the level of attractiveness of these subjects for students (how interesting they are for students in the context of their further career specialization)

- Part E: My education in the field of informatics (18 items)

- Assessment of some statements regarding the informatics education the students have already passed during their higher education study (estimation of the measure to which the students agree or do not agree with the given statements)

- Part F: My professional competencies in the context of the study specialization (7 items)

- Screening of the students' opinions on the development of their study specialization: how they assess their professional competency and how they assess their possibilities to employ on the labour market in the context of their study specialization

In the questionnaire parts $B-E$ the respondents expressed their opinions and assessments to the particular questionnaire items through five point Likert scale, i.e. through assessments from 1 to 5 points with a mean value to express neutral, emotionally indifferent evaluative answer. A higher level of the negative assessment or disagreement has been expressed by a lower point value, markedly negative assessment or a total disagreement has been expressed by the point value 1. A higher level of the positive assessment or agreement has been expressed by a higher point value, the maximum positive assessment or a total agreement has been expressed by the point (scale) value 5. At each respondent his/her responses to the particular items were recorded, i.e. one recorded the scale values by which the respondent assessed the particular informatics topic areas from the point of view of their interest and attractiveness for his/her study specialization, and the scale values corresponding to the degree of the respondent's agreement or disagreement with the particular given statements.

In the questionnaire part named My professional competencies in the context of the study specialization the respondents chose out of seven alternative answers the one which they identified mostly with, or which represented their viewpoint mostly.

The questionnaire survey for the purpose of the necessary research data collection was carried out in the academic year 2013/2014 in cooperation with the teachers of the concerned faculties who personally administrated the questionnaires.

Within the framework of the comparison analysis of the informatics education, carried out in the concerned study programmes in the Slovak and Czech Republics, in view of the database systems and database technology teaching as the data source, the relevant study programmes and information sheets of the particular subjects were used. 


\section{Data Analysis}

\section{a) Analysis of the informatics education}

At the Faculty of Economics and Management (FEM), Slovak University of Agriculture in Nitra (SUA Nitra), database systems and database technologies are taught within the course Managerial informatics in the second term of the first level of the tertiary study. Within this subject teaching the students should acquire basic knowledge on the key notions and conceptions regarding relational database technology, and skills to use databases in the Microsoft Access environment on the application level. Curriculum of the subject Managerial informatics creates a platform for students to pass a set of standardized certification exams on an advanced level of the ECDL (European Computer Driving Licence) system and to obtain the Expert version of the ECDL certificate, i.e. the subject should prepare students to be ready to obtain an internationally accepted document (certificate) on their computer literacy and digital expertise advanced level (ECDL, http://www.ecdl.sk/testy-ecdl/sylaby-ecdl-advanced). The basic knowledge from the subject Managerial informatics is further developed in the frame of the study programme Quantitative Methods in Economics (QME) in the first term of the second level of the tertiary study within the subject Database systems. The subject Database systems is a very important component part of both full- and part-time studies at the Faculty of European Studies and Regional Development (SUA Nitra), specifically of the study programme European Development Programmes. The main goal of this subject instruction is to make students both theoretically and practically acquainted with the core principles of database design and creation, which enables them, in the future at their job performance, to formulate requirements on the institutional information systems creation, modification and adaptation. Students are acquainted in a practical way with particular levels of the information systems, relational data models, relational algebra, query language principles, SQL language DML, DDL and DCL statements. Further, they are acquainted with a conceptual, database and physical data models, with data normalization, methodology of data model creation, data protection and integrity restrictions. To enroll the subject Database systems provides students a possibility to gain large knowledge of the use of different database models, algorithmization processes and standardization. Programming and development of the database systems are not incorporated in the informatics education curricula (as to the both faculties, i.e. FEM and FESRD). The closest knowledge to this issue, which students can obtain, is the knowledge and skills provided by the study subject Programming in applications taught at the Faculty of Economics and Management in the last term of the second level of the tertiary education.

In the Faculty of Business and Economics of Mendel University in Brno informatics subjects are an integral part of its study programmes, too. Ones of them are the study subjects Database systems I and Database systems II. Within the subject Database systems I, students learn to design database models for different applications, to describe and explain advanced SQL queries and their parts and to master SQL query logic. Students, passing this subject, are able to implement database models in the most common database systems. A continuation of the subject Database systems I, is the subject Database systems // taught at the second level of the tertiary (master) study. Passing this subject students are able to define and explain data analysis results on the reporting level, to design data warehouse model on the application level with its consequent optimization and to describe and carry out ETL process of data recording into the data warehouse. In general, the students are knowledgeable to create database queries on an advanced user level, including their optimizing strategies.

\section{b) Analysis of the reliability of the collected data}

Reliability of the created questionnaire was approved on the basis of its item reliability evaluation and suspicious questionnaire items identification by means of reliability/item analysis. The total reliability of the questionnaire was calculated through the Cronbach alpha coefficient. The Cronbach alpha values stated separately for all four areas $B-E a_{B}=0.9570$ (What I want to learn), $a_{C}=0.8405$ (My future profession), $a_{D}=0.9620$ (What I would like to learn) and $\mathrm{a}_{\mathrm{E}}=0.9293$ (My professional competencies in the context of the study specialization) indicate a high level of the internal consistency of the used measuring tool. 


\section{Results of Research}

Hereinafter there are presented the main results resulted from the analysis of the questionnaire items included in the questionnaire part named What I want to learn (items B1 - B26). In the primary plane, the attention is paid to the items related to the issues of database systems and database technologies instruction and issues of incorporating these topics into the informatics education carried out within the observed study programmes (i.e. with regard to the specialization of these study programme graduates).

\section{Table 2. Descriptive statistics to the selected questionnaire items from the part What I want to learn.}

\begin{tabular}{|c|c|c|c|c|c|}
\hline \multirow{2}{*}{ Questionnaire part/item } & \multirow{2}{*}{ Mean } & \multirow{2}{*}{$\begin{array}{l}\text { Standard } \\
\text { Deviation }\end{array}$} & \multirow{2}{*}{$\begin{array}{l}\text { Standard } \\
\text { Error }\end{array}$} & \multicolumn{2}{|c|}{$\begin{array}{l}95 \% \text { Confidence Interval for } \\
\text { the Mean }\end{array}$} \\
\hline & & & & $-95 \%$ & $+95 \%$ \\
\hline \multicolumn{6}{|l|}{ What I want to learn } \\
\hline $\begin{array}{l}\text { B6 - Use of tools and advanced techniques of work with MS } \\
\text { PowerPoint to create interactive presentations }\end{array}$ & 3.90 & 1.01 & 0.04 & 3.82 & 3.99 \\
\hline $\begin{array}{l}\text { B7 - Creating and formatting of structured documents using } \\
\text { MS Word tools }\end{array}$ & 3.85 & 1.01 & 0.04 & 3.76 & 3.94 \\
\hline B10 - Possibilities of conditional cell formatting in MS Excel & 3.53 & 1.08 & 0.05 & 3.44 & 3.62 \\
\hline B5 - Use of standard tools and Windows applications & 3.47 & 1.10 & 0.05 & 3.38 & 3.57 \\
\hline $\begin{array}{l}\text { B8 - Data entry through data form, formatting, data editing } \\
\text { and data back-up }\end{array}$ & 3.41 & 1.09 & 0.05 & 3.32 & 3.50 \\
\hline B16 - Using the tools for analytical output creation & 2.75 & 1.07 & 0.05 & 2.66 & 2.84 \\
\hline $\begin{array}{l}\text { B14 - Creation of own expressions by combining different } \\
\text { functions }\end{array}$ & 2.73 & 1.13 & 0.05 & 2.63 & 2.83 \\
\hline B20 - Defining relationship between database tables & 2.67 & 1.10 & 0.05 & 2.57 & 2.76 \\
\hline B1 - Algorithmization of mathematical problems solving & 2.16 & 1.15 & 0.05 & 2.07 & 2.26 \\
\hline $\begin{array}{l}\text { B3 - Number systems, transfer algorithms of numbers } \\
\text { between systems }\end{array}$ & 2.16 & 1.07 & 0.05 & 2.07 & 2.25 \\
\hline
\end{tabular}

Table 2 summarises descriptive statistics of the total score achieved in cases of the five most positively and most negatively assessed items - learning topics falling within the field of informatics (within the questionnaire part B What I want to learn). There are presented total scores of the items for the whole research sample without the respondent differentiation (i.e. without dividing the respondents into the subgroups on the basis of the factors COUNTRY, GENDER, FIELD OF STUDY), values of the mean, standard deviation, standard error of the estimated mean and $95 \%$ error band of the scale value mean.

The results of the assessments of the content attractiveness and importance of the topics selected in the questionnaire part What I want to learn (i.e. the assessment related to the subjects currently incorporated into the concerned study programmes) from the students' point of view are summarized in the graph in Figure 1. The box plot (Figure 1) presents mean, standard error of the estimated mean and standard deviation of the assessments of the particular items. 
TERTIARY ECINGMY AND MANAGERIAL STUDY FIELDS AND ISSUES IF SCIENGE EDUCATION AIMED ISSN 1648-3898 AT DATABASE SYSTEMS

(P. 535-555)

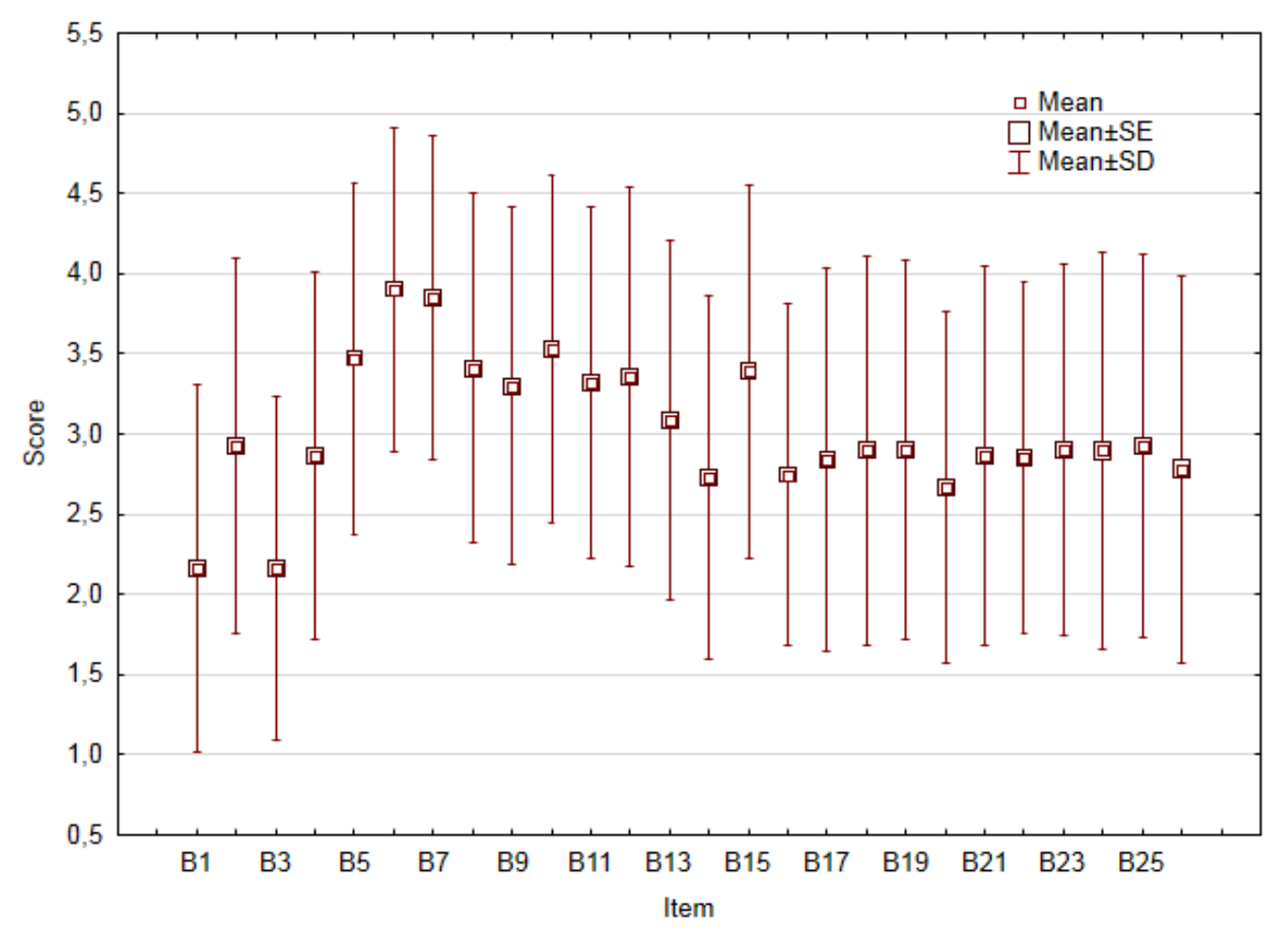

Figure 1: Box plot - differences in ratings of the particular items from the questionnaire part What I want to learn.

Explanatory notes: B1 - Algorithmization of mathematical problems solving; B2 - Computer hardware; B3 - Number systems, transfer algorithms of numbers between systems; B4 - Administration and orientation in structure of objects and data stored in Windows; B5 - Use of standard tools and Windows applications; B6 - Use of tools and advanced techniques of work with MS PowerPoint to create interactive presentations; B7 - Creating and formatting of structured documents using MS Word tools; B8 - Data entry through data form, formatting, data editing and data back-up; B9 - Creating documents for mail merge; B10 Possibilities of conditional cell formatting in MS Excel; B11 - Filtering large tables, defining filter criteria for the values of different formats; B12 - Use of functions; B13 - Work with large tables using data tools; B14 - Creation of own expressions by combining different functions; B15 - Graphical interpretation of data (creation and changing chart attributes); B16 - Using the tools for analytical output creation; B17 - Numerical and graphical analysis of data through the pivot table and pivot chart; B18 - Utilization of macros to automate repetitive operations in MS Excel; B19 - Definition of the table design in the MS Access database application; B20 - Defining relationship between database tables; B21 - Work with forms in MS Access database application; B22 - Selection of required data using select query; B23 - Creation of own calculations and use of functions in select query; B24 Using aggregate functions in queries for statistical, financial and economic data analysis; B25 - Creation of simple reports in MS Access; B26 - Dynamic interconnection of data between MS Access and external applications

A question is whether the differences among the statistic values of the respondents answers to the particular questionnaire items are random or statistically significant. To answer this question the repeated measures analysis of variance was used. It is necessary to point that the test was not applied on the dependence on the factors COUNTRY, GENDER and FIELD OF STUDY, as at the beginning of the sample survey the intention was to obtain only a global view on the observed issues, without any differentiation.

On the basis of the presented results of the description statistics, the following null hypothesis was formulated and consequently tested at the $5 \%$ significance level:

$\mathrm{HO}$ : There is no statistically significant difference between the assessments of the items B1 - B26 of the area "What I want to learn".

To the data obtained by the selective finding repeated measures ANOVA (analysis of variance) was applied. Assumption of the analysis of variance for repeated measures is equality of the variances and covariances in the covariant matrix for repeated measures, so-called assumption of the covariant matrix sphericity. The assumption of normality had not to be tested as the research samples were big enough. 
To test the equality of the variances and covariances in the covariant matrix Mauchly's sphericity test was used (Table 3).

Table 3. Mauchly's sphericity test.

\begin{tabular}{ccccc}
\hline Area of the survey /ltems & W & Chi-Sqr. & df & p \\
\hline What I want to learn / Item (B1-B26) & 0.002 & 3311.026 & 324 & 0.00000 \\
\hline
\end{tabular}

In case of the items (B1 - B26) the test is statistically significant $(p<0.05)$, so the assumption of the variance equality failed and so it is refused (Table 3 ).

If the assumption of the covariance matrix sphericity is not fulfilled, the value of the type I error increases. That is why in such cases degrees of freedom for the used F-test are revised by corrections to achieve the declared significance level. Because of the failure of the assumption of the variance analysis validity, there was used Greenhouse-Geisser and Huynh-Feldt correction for analysis of variance repeated measures (Table 4).

Table 4. Greenhouse-Geisser and Huynh-Feldt correction for analysis of variance repeated measures.

\begin{tabular}{|c|c|c|c|c|c|c|c|c|c|c|c|}
\hline & df & $F$ & $p$ & G-G & G-G & G-G & G-G & $\mathrm{H}-\mathrm{F}$ & $\mathrm{H}-\mathrm{F}$ & $\mathrm{H}-\mathrm{F}$ & $\mathrm{H}-\mathrm{F}$ \\
\hline & & & & Epsilon & Adj. df1 & Adj. df2 & Adj. $p$ & Epsilon & Adj. df1 & Adj. df2 & Adj. $p$ \\
\hline Item & 25 & 119.210 & 0.00000 & 0.589 & 14.728 & 7864.745 & 0.00000 & 0.607 & 15.170 & 8100.900 & 0.00000 \\
\hline Error & 13350 & & & & & & & & & & \\
\hline
\end{tabular}

The results of Greenhouse-Geisser and Huynh-Feldt correction for analysis of variance repeated measures to test the respondents` answers to the items B1 - B26 (Table 4) proved the statistical significance of the differences between the respondents' assessments of the particular items within the studied area $(p<0.05)$. Following the obtained results (the achieved significance values in all three cases are the same) the above-stated null hypothesis $\mathrm{HO}$ was disapproved at the $5 \%$ significance level.

Within the tests also Friedman test and Kendall's coefficient of concordance were applied. The results of Friedman's test (ANOVA Chi Sqr. $(N=535, d f=25)=2404.36 ; p=0.00000)$ and achieved values of Kendall's coefficient of concordance (Coeff. of Concordance $=0.18$ ) have proved Greenhouse-Geisser and Huynh-Feldt correction results $(p<0.05)$. The results are consistent, so they can be taken as robust.

After the approval of the statistically significant differences among the respondents' answers to the items B1 - B6 of the questionnaire part What I want to learn the differences in the assessment were tested to find those items between responses to which the differences are statistically significant. The identification of the homogeneous groups in the concerned part was done by the means of the repeated comparison of the particular couples. Overview of the repeated comparison is presented in Table 5.

Table 5. Identification of the homogeneous groups.

\begin{tabular}{|c|c|c|c|c|c|c|c|c|}
\hline Item & Mean & 1 & 2 & 3 & 4 & 5 & 6 & 7 \\
\hline B3 & 2.160748 & $* * * *$ & & & & & & \\
\hline B1 & 2.162617 & $* * * *$ & & & & & & \\
\hline B20 & 2.665421 & & $* * * *$ & & & & & \\
\hline B14 & 2.730841 & & $* * * *$ & $* \star * *$ & & & & \\
\hline B16 & 2.747664 & & $* * * *$ & $* * * *$ & & & & \\
\hline B26 & 2.783178 & & $* * * *$ & $* * * *$ & & & & \\
\hline B17 & 2.839252 & & $* * * *$ & $* * * *$ & & & & \\
\hline
\end{tabular}




\begin{tabular}{|c|c|c|c|c|c|c|c|c|}
\hline Item & Mean & 1 & 2 & 3 & 4 & 5 & 6 & 7 \\
\hline B22 & 2.850467 & & $* * * *$ & $\star \star \star \star *$ & & & & \\
\hline B4 & 2.865421 & & $* * * *$ & $* * * *$ & & & & \\
\hline B21 & 2.869159 & & & $* * * *$ & & & & \\
\hline B24 & 2.897196 & & & $* * * *$ & $* * * *$ & & & \\
\hline B19 & 2.900935 & & & $* * \star *$ & $* * * *$ & & & \\
\hline B18 & 2.900935 & & & $* * \star *$ & $* * * *$ & & & \\
\hline B23 & 2.904673 & & & $* * \star *$ & $* * \star *$ & & & \\
\hline B2 & 2.925234 & & & $* * * *$ & $* * * *$ & & & \\
\hline B25 & 2.928972 & & & $* * * *$ & $* * \star *$ & & & \\
\hline B13 & 3.085981 & & & & $* * * *$ & & & \\
\hline B9 & 3.299065 & & & & & $\star * * *$ & & \\
\hline B11 & 3.321495 & & & & & $* * * *$ & & \\
\hline B12 & 3.357009 & & & & & $\star * * *$ & $* * * *$ & \\
\hline B15 & 3.394393 & & & & & $\star * \star *$ & $* * * *$ & \\
\hline B8 & 3.411215 & & & & & $\star * * *$ & 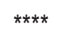 & \\
\hline B5 & 3.474766 & & & & & $* * * *$ & $* * * *$ & \\
\hline B10 & 3.530841 & & & & & & $* * \star *$ & \\
\hline B7 & 3.850467 & & & & & & & $* * * *$ \\
\hline B6 & 3.902804 & & & & & & & **** \\
\hline
\end{tabular}

Within the identified seven homogeneous groups the respondents (without their differentiation according to the factors COUNTRY, GENDER and FIELD OF STUDY) responded almost identically.

Following the obtained results and particular findings, the further subject of the research was to find out the divergence of the means of the particular item scores (B1 - B26) in dependence on the factors COUNTRY, GENDER and FIELD OF STUDY. From the whole statistics evaluation only the results regarding database systems and database technologies, i.e. items B19, B20, B21, B22, B24 and B26 are presented. The results recorded at these items are summarised in Table 6 . It is an overview of the values of the means, standard deviations, standard errors of the mean estimation and $95 \%$ confidence intervals of the means of the scale value processed for the whole research sample (total) and for the sub-samples differentiated in dependence on the factors COUNTRY (SK, CZ), GENDER (F, $M)$ and FIELD OF STUDY (BEC, ATM, QME, AC, BMA, EDP, ACT, EPA).

Table 6. Descriptive statistics for selected items from the part What I want to learn.

\begin{tabular}{|c|c|c|c|c|c|c|c|c|c|c|}
\hline \multirow{2}{*}{$\begin{array}{c}\text { B19 / B20 } \\
\text { Level of } \\
\text { Factor }\end{array}$} & \multirow{2}{*}{$\begin{array}{l}\text { B19 } \\
\text { Mean }\end{array}$} & \multirow[b]{2}{*}{$\begin{array}{l}\text { Std. } \\
\text { Dev. }\end{array}$} & \multirow[b]{2}{*}{ Std.Err. } & \multicolumn{2}{|c|}{$\begin{array}{l}95 \% \text { Confidence } \\
\text { Interval for the Mean }\end{array}$} & \multirow{2}{*}{$\begin{array}{l}\text { B20 } \\
\text { Mean }\end{array}$} & \multirow[b]{2}{*}{$\begin{array}{l}\text { Std. } \\
\text { Dev. }\end{array}$} & \multirow[b]{2}{*}{ Std.Err. } & \multicolumn{2}{|c|}{$\begin{array}{l}95 \% \text { Confidence } \\
\text { Interval for the Mean }\end{array}$} \\
\hline & & & & $-95 \%$ & $+95 \%$ & & & & $-95 \%$ & $+95 \%$ \\
\hline Total & 2.90 & 1.18 & 0.05 & 2.80 & 3.00 & 2.67 & 1.10 & 0.05 & 2.57 & 2.76 \\
\hline SR & 2.90 & 1.16 & 0.05 & 2.80 & 3.01 & 2.65 & 1.07 & 0.05 & 2.55 & 2.74 \\
\hline$C Z$ & 2.86 & 1.39 & 0.21 & 2.42 & 3.29 & 2.86 & 1.42 & 0.22 & 2.41 & 3.30 \\
\hline $\mathrm{F}$ & 2.96 & 1.19 & 0.06 & 2.84 & 3.08 & 2.70 & 1.11 & 0.06 & 2.59 & 2.82 \\
\hline$M$ & 2.77 & 1.15 & 0.09 & 2.59 & 2.95 & 2.58 & 1.06 & 0.08 & 2.42 & 2.74 \\
\hline BEC & 2.94 & 1.13 & 0.06 & 2.81 & 3.06 & 2.68 & 1.04 & 0.06 & 2.57 & 2.80 \\
\hline ATM & 2.89 & 1.20 & 0.15 & 2.58 & 3.19 & 2.69 & 1.10 & 0.14 & 2.42 & 2.97 \\
\hline QME & 3.61 & 1.03 & 0.19 & 3.21 & 4.01 & 3.21 & 1.20 & 0.23 & 2.75 & 3.68 \\
\hline
\end{tabular}




\begin{tabular}{|c|c|c|c|c|c|c|c|c|c|c|}
\hline \multirow{2}{*}{$\begin{array}{c}\text { B19 / B20 } \\
\text { Level of } \\
\text { Factor }\end{array}$} & \multirow{2}{*}{$\begin{array}{l}\text { B19 } \\
\text { Mean }\end{array}$} & \multirow[b]{2}{*}{$\begin{array}{l}\text { Std. } \\
\text { Dev. }\end{array}$} & \multirow[b]{2}{*}{ Std.Err. } & \multicolumn{2}{|c|}{$\begin{array}{l}95 \% \text { Confidence } \\
\text { Interval for the Mean }\end{array}$} & \multirow{2}{*}{$\begin{array}{l}\text { B20 } \\
\text { Mean }\end{array}$} & \multirow[b]{2}{*}{$\begin{array}{l}\text { Std. } \\
\text { Dev. }\end{array}$} & \multirow[b]{2}{*}{ Std.Err. } & \multicolumn{2}{|c|}{$\begin{array}{l}95 \% \text { Confidence } \\
\text { Interval for the Mean }\end{array}$} \\
\hline & & & & $-95 \%$ & $+95 \%$ & & & & $-95 \%$ & $+95 \%$ \\
\hline$A C$ & 2.84 & 1.07 & 0.18 & 2.48 & 3.19 & 2.70 & 0.94 & 0.15 & 2.39 & 3.02 \\
\hline BMA & 2.55 & 1.28 & 0.29 & 1.95 & 3.15 & 2.20 & 0.83 & 0.19 & 1.81 & 2.59 \\
\hline EDP & 2.19 & 1.21 & 0.23 & 1.71 & 2.66 & 1.85 & 0.99 & 0.19 & 1.46 & 2.24 \\
\hline $\mathrm{ACT}$ & 2.83 & 1.58 & 0.37 & 2.05 & 3.62 & 2.78 & 1.48 & 0.35 & 2.04 & 3.51 \\
\hline EPA & 2.88 & 1.26 & 0.26 & 2.34 & 3.41 & 2.92 & 1.41 & 0.29 & 2.32 & 3.51 \\
\hline \multirow{2}{*}{$\begin{array}{c}\text { B21 / B22 } \\
\text { Level of } \\
\text { Factor }\end{array}$} & \multirow[b]{2}{*}{ Mean } & \multirow[b]{2}{*}{$\begin{array}{l}\text { Std. } \\
\text { Dev. }\end{array}$} & \multirow[b]{2}{*}{ Std.Err. } & \multicolumn{2}{|c|}{$\begin{array}{l}95 \% \text { Confidence } \\
\text { Interval for the Mean }\end{array}$} & \multirow{2}{*}{$\begin{array}{l}\text { B22 } \\
\text { Mean }\end{array}$} & \multirow[b]{2}{*}{$\begin{array}{l}\text { Std. } \\
\text { Dev. }\end{array}$} & \multirow[b]{2}{*}{ Std.Err. } & \multicolumn{2}{|c|}{$\begin{array}{l}95 \% \text { Confidence } \\
\text { Interval for the Mean }\end{array}$} \\
\hline & & & & $-95 \%$ & $+95 \%$ & & & & $-95 \%$ & $+95 \%$ \\
\hline Total & 2.87 & 1.18 & 0.05 & 2.77 & 2.97 & 2.85 & 1.10 & 0.05 & 2.76 & 2.94 \\
\hline SR & 2.87 & 1.16 & 0.05 & 2.77 & 2.98 & 2.85 & 1.09 & 0.05 & 2.76 & 2.95 \\
\hline$C Z$ & 2.83 & 1.40 & 0.22 & 2.40 & 3.27 & 2.81 & 1.25 & 0.19 & 2.42 & 3.20 \\
\hline $\mathrm{F}$ & 2.91 & 1.19 & 0.06 & 2.79 & 3.03 & 2.86 & 1.07 & 0.06 & 2.75 & 2.97 \\
\hline$M$ & 2.78 & 1.17 & 0.09 & 2.60 & 2.97 & 2.83 & 1.16 & 0.09 & 2.65 & 3.01 \\
\hline BEC & 2.91 & 1.13 & 0.06 & 2.78 & 3.03 & 2.92 & 1.10 & 0.06 & 2.80 & 3.05 \\
\hline ATM & 2.77 & 1.18 & 0.15 & 2.47 & 3.07 & 2.65 & 1.04 & 0.13 & 2.38 & 2.91 \\
\hline QME & 3.75 & 0.97 & 0.18 & 3.38 & 4.12 & 3.39 & 0.92 & 0.17 & 3.04 & 3.75 \\
\hline$A C$ & 2.84 & 1.21 & 0.20 & 2.43 & 3.24 & 2.62 & 1.11 & 0.18 & 2.25 & 2.99 \\
\hline BMA & 2.65 & 1.18 & 0.26 & 2.10 & 3.20 & 2.85 & 0.75 & 0.17 & 2.50 & 3.20 \\
\hline EDP & 2.00 & 1.07 & 0.21 & 1.58 & 2.42 & 2.26 & 1.06 & 0.20 & 1.84 & 2.68 \\
\hline $\mathrm{ACT}$ & 2.83 & 1.58 & 0.37 & 2.05 & 3.62 & 2.78 & 1.31 & 0.31 & 2.13 & 3.43 \\
\hline EPA & 2.83 & 1.27 & 0.26 & 2.30 & 3.37 & 2.83 & 1.24 & 0.25 & 2.31 & 3.36 \\
\hline \multirow{2}{*}{$\begin{array}{c}\text { B24 / B26 } \\
\text { Level of } \\
\text { Factor }\end{array}$} & \multirow{2}{*}{$\begin{array}{l}\text { B24 } \\
\text { Mean }\end{array}$} & \multirow[b]{2}{*}{$\begin{array}{l}\text { Std. } \\
\text { Dev. }\end{array}$} & \multirow[b]{2}{*}{ Std.Err. } & \multicolumn{2}{|c|}{$\begin{array}{l}95 \% \text { Confidence } \\
\text { Interval for the Mean }\end{array}$} & \multirow{2}{*}{$\begin{array}{l}\text { B26 } \\
\text { Mean }\end{array}$} & \multirow[b]{2}{*}{$\begin{array}{l}\text { Std. } \\
\text { Dev. }\end{array}$} & \multirow[b]{2}{*}{ Std.Err. } & \multicolumn{2}{|c|}{$\begin{array}{l}95 \% \text { Confidence } \\
\text { Interval for the Mean }\end{array}$} \\
\hline & & & & $-95 \%$ & $+95 \%$ & & & & $-95 \%$ & $+95 \%$ \\
\hline Total & 2.90 & 1.24 & 0.05 & 2.79 & 3.00 & 2.78 & 1.20 & 0.05 & 2.68 & 2.89 \\
\hline SR & 2.88 & 1.23 & 0.06 & 2.77 & 2.98 & 2.80 & 1.19 & 0.05 & 2.70 & 2.91 \\
\hline $\mathrm{CZ}$ & 3.14 & 1.34 & 0.21 & 2.73 & 3.56 & 2.55 & 1.35 & 0.21 & 2.13 & 2.97 \\
\hline $\mathrm{F}$ & 2.86 & 1.27 & 0.07 & 2.73 & 2.99 & 2.77 & 1.19 & 0.06 & 2.65 & 2.89 \\
\hline$M$ & 2.98 & 1.15 & 0.09 & 2.80 & 3.15 & 2.81 & 1.25 & 0.10 & 2.61 & 3.00 \\
\hline BEC & 2.97 & 1.19 & 0.07 & 2.83 & 3.10 & 2.89 & 1.13 & 0.06 & 2.77 & 3.02 \\
\hline ATM & 2.56 & 1.20 & 0.15 & 2.26 & 2.87 & 2.65 & 1.20 & 0.15 & 2.34 & 2.95 \\
\hline QME & 3.75 & 0.80 & 0.15 & 3.44 & 4.06 & 3.39 & 1.20 & 0.23 & 2.93 & 3.86 \\
\hline$A C$ & 2.76 & 1.21 & 0.20 & 2.35 & 3.16 & 2.59 & 1.30 & 0.21 & 2.16 & 3.03 \\
\hline BMA & 2.60 & 1.14 & 0.26 & 2.07 & 3.13 & 2.60 & 1.23 & 0.28 & 2.02 & 3.18 \\
\hline
\end{tabular}



TERTIARY ECINGMY AND MANAGERIAL STUDY FIELDS AND ISSUES GF SCIENCE EDUCATION AIMED ISSN $1648-3898$ AT DATABASE SYSTEMS

(P. 535-555)

\begin{tabular}{|c|c|c|c|c|c|c|c|c|c|c|}
\hline \multirow{2}{*}{$\begin{array}{c}\text { B24 / B26 } \\
\text { Level of } \\
\text { Factor }\end{array}$} & \multirow{2}{*}{$\begin{array}{l}\text { B24 } \\
\text { Mean }\end{array}$} & \multirow[b]{2}{*}{$\begin{array}{l}\text { Std. } \\
\text { Dev. }\end{array}$} & \multirow[b]{2}{*}{ Std.Err. } & \multicolumn{2}{|c|}{$\begin{array}{l}95 \% \text { Confidence } \\
\text { Interval for the Mean }\end{array}$} & \multirow{2}{*}{$\begin{array}{l}\text { B26 } \\
\text { Mean }\end{array}$} & \multirow[b]{2}{*}{$\begin{array}{l}\text { Std. } \\
\text { Dev. }\end{array}$} & \multirow[b]{2}{*}{ Std.Err. } & \multicolumn{2}{|c|}{$\begin{array}{l}95 \% \text { Confidence } \\
\text { Interval for the Mean }\end{array}$} \\
\hline & & & & $-95 \%$ & $+95 \%$ & & & & $-95 \%$ & $+95 \%$ \\
\hline EDP & 2.00 & 1.44 & 0.28 & 1.43 & 2.57 & 1.96 & 1.19 & 0.23 & 1.49 & 2.43 \\
\hline ACT & 3.06 & 1.30 & 0.31 & 2.41 & 3.70 & 2.44 & 1.42 & 0.34 & 1.74 & 3.15 \\
\hline EPA & 3.21 & 1.38 & 0.28 & 2.62 & 3.79 & 2.63 & 1.31 & 0.27 & 2.07 & 3.18 \\
\hline
\end{tabular}

Before the valid use of the analysis of variance to test the differences of more means, there was applied Hartley, Cochran and Bartlett test (univariate tests on variance) to prove that in case of all tested items the presumption of equality of variances, which the tested data have to fulfil, was not broken $(p>0.05)$.

Dependence of the respondent's answers on the factors COUNTRY, GENDER and FIELD OF STUDY was tested for all items of the questionnaire part B1 - B26, not only for the mentioned ones B19-B22, B24 and B26. It means that the validity of the following three null hypotheses, from which each one represents de facto 26 partial null hypotheses, was verified:

$H_{0}$ : Answers to the items B1 - B26 in the area "What I want to learn" do not depend on the factor COUNTRY.

$H_{0}$ : Answers to the items B1 - B26 in the area "What I want to learn" do not depend on the factor GENDER.

$H_{0}$ : Answers to the items B1 - B26 in the area "What I want to learn" do not depend on the factor FIELD OF STUDY.

Dependence and independence on the particular factors, stated in the above-mentioned hypotheses, was tested by the means of parametric tests. In case of the items B19, B20, B21, B22, B24 and B26 the dependence was proved only in relation to the factor FIELD OF STUDY.

Depending on the factor COUNTRY is the $p$ value higher than the chosen significance level $(5 \%=0.05)$ for each of the tested items B19, B20, B21, B22, B24 a B26, what means that in dependence on the factor COUNTRY there was not proved any statistically significant difference among the responses to these items.

A similar situation can be found at the assessments of the given items in dependence on the factor GENDER. Depending on this factor boys and girls' responses to the items do not differ significantly. This is proved by the results of the analysis of variance (at none of the tested items the $p$ value was lower than 0.05 ), what means that the differences between the corresponding values of means calculated for the relevant groups are only a consequence of the random selection of the research samples. As it was already above-mentioned, the results of the statistical analysis proved the null hypothesis, according to which responses of the respondents to the items B19-B22, B24 and B26 do not depend on the factor GENDER.

As it follows from the results of the analysis of variance summarised in Table 7, at testing the dependence of the responses on the factor FIELD OF STUDY the $p$ value was lower than 0.05 , based on what the null hypothesis was rejected and it was stated that the respondent study specialization has a significant influence on how they evaluate the tested items B19, B20, B21, B22, B24 and B26.

Table 7. Analysis of variance for the factor Field of study.

\begin{tabular}{|c|c|c|c|c|c|c|c|c|}
\hline \multirow{2}{*}{ Item } & \multicolumn{4}{|l|}{ B19 } & \multicolumn{4}{|l|}{ B20 } \\
\hline & SS & MS & $F$ & $p$ & SS & MS & $F$ & $p$ \\
\hline Intercept & 1937.457 & 1937.457 & 1428.406 & 0.000000 & 1662.103 & 1662.103 & 1434.634 & 0.000000 \\
\hline St. Field & 30.939 & 4.420 & 3.259 & 0.002136 & 32.551 & 4.650 & 4.014 & 0.000271 \\
\hline Error & 714.810 & 1.356 & & & 610.559 & 1.159 & & \\
\hline Total & 745.750 & & & & 643.110 & & & \\
\hline
\end{tabular}




\begin{tabular}{|c|c|c|c|c|c|c|c|c|}
\hline \multirow{2}{*}{ Item } & \multicolumn{4}{|l|}{ B21 } & \multicolumn{4}{|l|}{ B22 } \\
\hline & SS & MS & $F$ & $p$ & SS & MS & $F$ & $p$ \\
\hline Intercept & 1915.640 & 1915.640 & 1436.707 & 0.000000 & 1868.455 & 1868.455 & 1588.318 & 0.00000 \\
\hline St. Field & 44.163 & 6.309 & 4.732 & 0.000036 & 24.089 & 3.441 & 2.925 & 0.005186 \\
\hline Error & 702.678 & 1.333 & & & 619.949 & 1.176 & & \\
\hline Total & 746.841 & & & & 644.037 & & & \\
\hline \multirow{2}{*}{ Item } & B24 & & & & B26 & & & \\
\hline & SS & MS & $F$ & $p$ & SS & MS & $F$ & $p$ \\
\hline Intercept & 1969.625 & 1969.625 & 1366.452 & 0.000000 & 1680.836 & 1680.836 & 1202.254 & 0.000000 \\
\hline St. Field & 55.720 & 7.960 & 5.522 & 0.000004 & 38.065 & 5.438 & 3.890 & 0.000382 \\
\hline Error & 759.626 & 1.441 & & & 736.783 & 1.398 & & \\
\hline Total & 815.346 & & & & 774.849 & & & \\
\hline
\end{tabular}

To the graphical visualisation of the respondents`assessments to the given selected items (related to the issues of database systems and database technologies) in dependence on the factor FIELD OF STUDY there were used dot and interval diagrams of the average score estimation of the relevant items assessments (Figure 2). The graphical interpretation of the achieved results shows a slight shift of the opinions in the given items assessments between the group of the QME study programme students and the groups of the other study programme students.

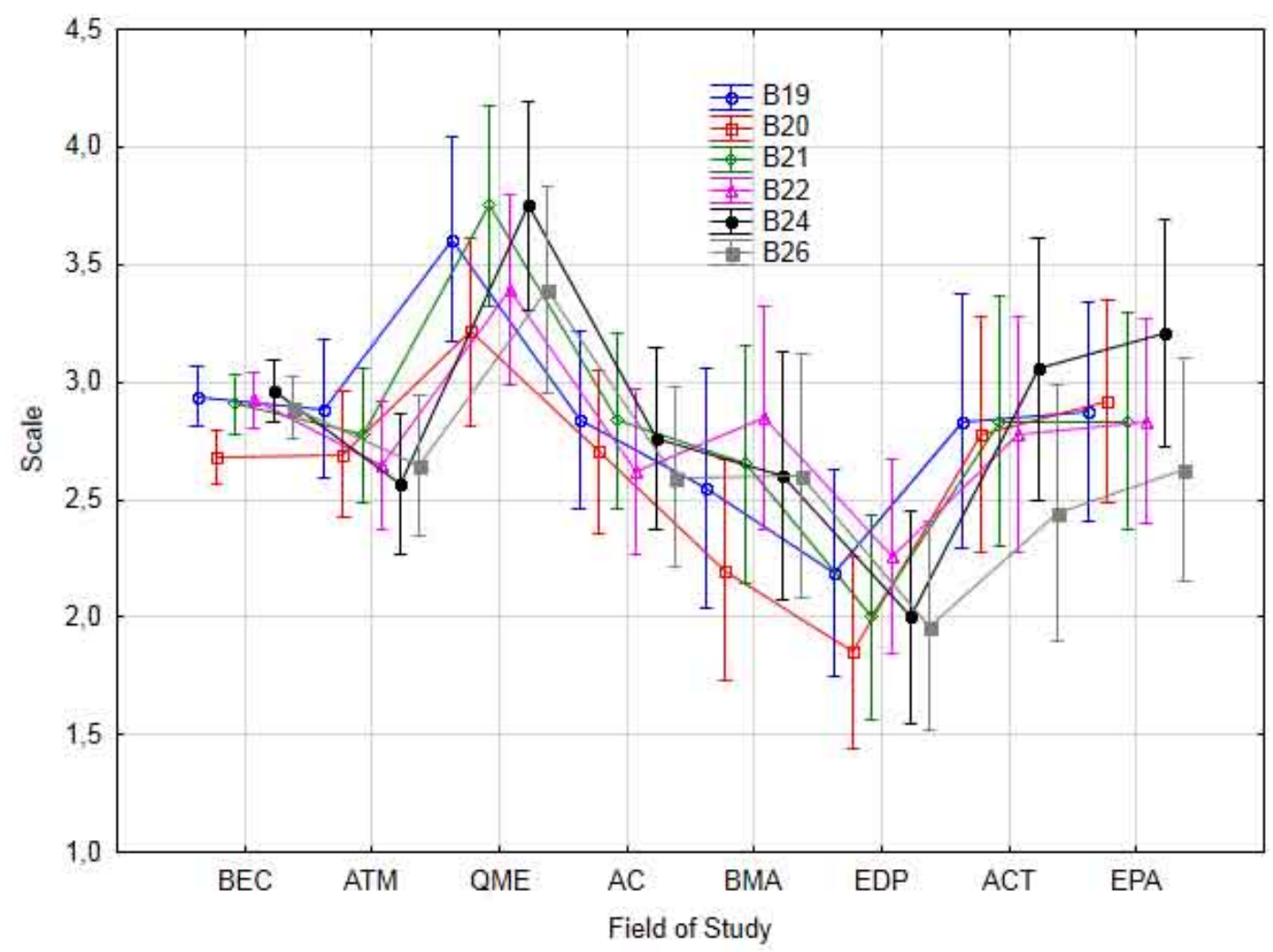

Figure 2: Dot and interval estimation of the average score to the selected items in dependence on the factor Field of Study. 
TERTIARY ELINIMY AND MANAGERIAL STUDY FIELDS AND ISSUES IF SCIENCE EDUCATION AIMED ISSN 1648-3898 AT DATABASE SYSTEMS

(P. 535-555)

After the approval of the statistically significant differences among the respondents` answers in dependence on the factor FIELD OF STUDY, there was a search for the study groups between which in the context of their various study specializations this occurs. The identification of the homogeneous groups in dependence on the factor FIELD OF STUDY was done by the means of the multiple comparison of the particular couples of the groups. Overview of the relevant results is presented in Table 8.

Depending on the factor FIELD OF STUDY the average scores of the responses to the items B19, B20, B21, B22, B24 and B26 take a value from 1.85 (rather uninteresting) even to 3.75 (rather interesting) from the maximum scale value (Table 8). The lowest mean of the response values, among all the observed items focused on database systems and database technology issues, was recorded in the group of EDP (European Development Programmes) study programme. This study programme students evaluated the given learning topics rather in a negative way. The highest average score, in case of the respondents differentiation according to the factor FIELD OF STUDY, was recorded at the group of QME (Quantitative Methods in Economics) study programme students at two items, in particular B21 (work with forms in MS Access database application) and B24 (using aggregate functions in queries for statistical, financial and economic data analysis), equally 3.75 (rather interesting).

At the items B19, B20, B21, B22 and B26 two homogeneous groups have been proved, and at the item B24 three homogeneous groups. The data presented in Table 8 show that the homogeneous groups overlap in the case of the assessment of all six items at the groups of respondents - students of the study programmes ACT, BMA, BEC and AC. At the item B24 there is an overlap only at two first homogeneous groups of the ATM study programme students and at the last two homogeneous groups of the EPA study programme students.

Table 8. Identification of the homogeneous groups at the respondent differentiation according to the factor Field of Study.

\begin{tabular}{|c|c|c|c|c|c|c|c|}
\hline $\begin{array}{c}\text { Item } \\
\text { St. Field }\end{array}$ & $\begin{array}{c}\text { B19 } \\
\text { Mean }\end{array}$ & 1 & 2 & $\begin{array}{c}\text { Item } \\
\text { St. Field }\end{array}$ & $\begin{array}{c}\text { B20 } \\
\text { Mean }\end{array}$ & 1 & 2 \\
\hline EDP & 2.185185 & $* * * *$ & & EDP & 1.851852 & & $* * * *$ \\
\hline BMA & 2.550000 & $* * * *$ & $* * * *$ & BMA & 2.200000 & $* * * *$ & $* * * *$ \\
\hline ACT & 2.833333 & $* * * *$ & $* * * *$ & BEC & 2.680251 & $* * * *$ & $* * * *$ \\
\hline$A C$ & 2.837838 & $* * * *$ & $* * * *$ & ATM & 2.693548 & $* * * *$ & $* * * *$ \\
\hline EPA & 2.875000 & $* \star \star *$ & $* * * *$ & $A C$ & 2.702703 & $* * * *$ & $* * * *$ \\
\hline ATM & 2.887097 & $* \star * *$ & $* * * *$ & ACT & 2.777778 & $* * * *$ & $* * * *$ \\
\hline BEC & 2.937304 & $* * * *$ & $* * * *$ & EPA & 2.916667 & $* * * *$ & \\
\hline QME & 3.607143 & & $* * * *$ & QME & 3.214286 & $* * * *$ & \\
\hline $\begin{array}{c}\text { Item } \\
\text { St. Field }\end{array}$ & $\begin{array}{c}\text { B21 } \\
\text { Mean }\end{array}$ & 1 & 2 & $\begin{array}{c}\text { Item } \\
\text { St. Field }\end{array}$ & $\begin{array}{c}\text { B22 } \\
\text { Mean }\end{array}$ & 1 & 2 \\
\hline EDP & 2.000000 & $* * * *$ & & EDP & 2.259259 & $* * \star *$ & \\
\hline BMA & 2.650000 & $* * * *$ & $* * * *$ & $A C$ & 2.621622 & $* * * *$ & $* * * *$ \\
\hline ATM & 2.774194 & $* \star \star *$ & $* * * *$ & ATM & 2.645161 & $* * * *$ & $* * * *$ \\
\hline EPA & 2.833333 & $* * * *$ & $* * * *$ & ACT & 2.777778 & $* * * *$ & $* * * *$ \\
\hline ACT & 2.833333 & $* * * *$ & $* * * *$ & EPA & 2.833333 & $* * * *$ & $* * * *$ \\
\hline$A C$ & 2.837838 & $* * * *$ & $* * * *$ & BMA & 2.850000 & $* * * *$ & $* * * *$ \\
\hline BEC & 2.905956 & $* * * *$ & $* * * *$ & BEC & 2.924765 & $* * * *$ & $* * * *$ \\
\hline QME & 3.750000 & & $* * * *$ & QME & 3.392857 & & $* \star \star * *$ \\
\hline
\end{tabular}




\begin{tabular}{ccccc}
\hline $\begin{array}{c}\text { Item } \\
\text { St. Field }\end{array}$ & $\begin{array}{c}\text { B24 } \\
\text { Mean }\end{array}$ & 1 & 2 & 3 \\
\hline EDP & 2.000000 & $* * * *$ & & \\
ATM & 2.564516 & $* * * *$ & $* * * *$ & \\
BMA & 2.600000 & $* * * *$ & $* * * *$ & $* * * *$ \\
AC & 2.756757 & $* * * *$ & $* * * *$ & $* * * *$ \\
BEC & 2.965517 & $* * * *$ & $* * * *$ & $* * * *$ \\
ACT & 3.055556 & $* * * *$ & $* * * *$ & $* * * *$ \\
EPA & 3.208333 & & $* * * *$ & $* * * *$ \\
QME & 3.750000 & & & $* * * *$ \\
\hline
\end{tabular}

\begin{tabular}{cccc}
\hline $\begin{array}{c}\text { Item } \\
\text { St. Field }\end{array}$ & $\begin{array}{c}\text { B26 } \\
\text { Mean }\end{array}$ & 1 & 2 \\
\hline EDP & 1.962963 & $* * * *$ & \\
ACT & 2.444444 & $* * * *$ & $* * * *$ \\
AC & 2.594595 & $* * * *$ & $* * * *$ \\
BMA & 2.600000 & $* * * *$ & $* * * *$ \\
EPA & 2.625000 & $* * * *$ & $* * * *$ \\
ATM & 2.645161 & $* * * *$ & $* * * *$ \\
BEC & 2.890282 & $* * * *$ & $* * * *$ \\
QME & 3.392857 & & $* * * *$ \\
\hline
\end{tabular}

Testing the significance of the differences among the means of the items B19, B20, B21, B22, B24 and B26, only the difference between the groups of QME and EDP study programme students has been proved. This result can have a bearing on the fact that students of the study programme QME (Quantitative Methods in Economics), following the structure of the learning courses (subjects) included in their study programme, are led to a more intense use of the software products and engineering and economical ICT applications in comparison to the EDP (European Development Programmes) study programme students. The structure of compulsory, compulsory optional and optional subjects from the informatics area offered within the particular study programmes is almost identical, with the exception of the subject structure of the QME study programme, but in their topical curricula none of the subjects goes deeper into the concerned issues.

The results of the variance analysis (Table 8) prove the statistical significance of the differences also among the responses of the respondent groups - students of the EDP and EPA study programmes, in particular at the item B20 (defining the relationship between database tables), and the respondent groups - students of the ATM and QME study programmes at the item B21 (work with forms in MS Access database application). In case of the item B24 assessment (using aggregate functions in queries for statistical, financial and economic data analysis), where three homogeneous groups were identified, statistically significant differences between the answers of the particular groups of the respondents were proved, similarly to the items B20 and B21, at the respondents with study specialization ATM and QME, or EDP and EPA.

Following the average scores of the responses to the items B19, B20, B21, B22, B24 and B26 in the context of the respondent differentiation according to the factor FIELD OF STUDY there is no marked favour (popularity) of the learning topics related to database systems and database technologies, in the observed study specializations. The values of the average score are mostly at the scale level 3 (neither interesting nor uninteresting). Deviation from this neutral response is noticeable in the group of BMA study programme students at the assessment of the interest/attractiveness of the topic defining relationship between database tables (B20) and in the group of EDP study programme students at the assessment of all six items related to the database systems and database technology issues. In these cases the average values of the responses are about the scale level 2 (rather uninteresting).

\section{Discussion}

As the results presented in Table 2 and Figure 1 show, the respondents` responses regarding attractiveness (interest) of the selected learning topics in the field of informatics were mostly neutral (at the scale value 3 - neither interesting, neither uninteresting). The average score of the responses for the whole research sample, i.e. without any differentiation according to the given factors, for the part What I want to learn ranges from the value 2.16 ( 2 - rather uninteresting) to the value 3.9 ( 4 - rather interesting) from the maximum scale value 5 (5 - very interesting). In our opinion the achieved average score follows rather a lower attractiveness of the learning topics, which are included in the informatics part of the curricula of the concerned study programmes of the respondents. However, these results can be viewed from the point of view of different aspects. On the 
one hand, discussions could be led in a context of the surveyed study programmes innovation and modernization. On the other hand, a question arises to which level, from the students point of view, to these subjects relevant education content is fulfilled.

Relatively a more positive situation is in the evaluation of the questionnaire items B6 (3.90), B7 (3.85) and B10 (3.53), at which the topics were assessed by the respondents as rather interesting. In all three cases the assessed issues is a part of the content of the subject Managerial informatics incorporated in the second term of the general basis of the study programmes at the Faculty of Economics and Management of the Slovak University of Agriculture in Nitra, or of the subject Informatics for economists of the students of the Faculty of Business and Economics at the Mendel University in Brno. Visualization of the results of the students 'assessments of the particular items (Figure 1) clearly shows that among all of them significantly the highest score was recorded at the item B6 (mean 3.95 from the 5 point scale). At the same time the lowest value of the standard deviation (1.01) was recorded at the items B6 and B7, what means the lowest variability of the respondents` responses (B6 - from 3.82 to 3.99; B7 - from 3.76 to 3.94). In this way the respondents declared their opinion that the use of tools and advanced techniques of work with MS PowerPoint to create interactive presentations as well as creating and formatting of structured documents using MS Word tools, which they do within the informatics lessons, are for them interesting properly or enough.

From the result tabulation (Table 2) can be seen that totally the lowest average score in the discussed questionnaire part was recorded at the items B3 (2.16) and B1 (2.16). This result proves that the students are less interested in studying the issues of algorithmization of mathematical problems solving (B1) and number systems and transfer algorithms of numbers between the systems (B3). In a great measure it can be influenced by the tasks which the students solve at the lessons, i.e. it can be a consequence of the fact that they solve only trivial uninteresting problems. Here a challenge for teachers arises to use such kinds of application tasks and case studies which would be more motivating for the students and would lead them to apply the acquired knowledge in real situations with the stress on the situations corresponding to the area of their study specializations.

The topics B3 and B1 are assessed by the students as uninteresting in the context of their study specializations, however, we consider them to be important for the students as the application of the creative algorithmic and mathematical thinking at solving appropriate tasks contributes significantly to the development of new competencies whether in the advanced work with data using the SQL database instruction language or in development of different applications in the MS Excel or MS Access by means of programming in the Visual Basic program language.

Following the descriptive statistics one can state that the standard deviation result values of the respondents 'answers to the particular items do not differ. Values of the particular responses, in regard to the interval estimation of the mean, range from $2.07(B 1, B 7)$ up to 3.99 (B6), what means within the used scale assessments the range from rather uninteresting (2) to rather interesting (4). If we have a detailed look at the obtained results from this statistic index point of view, the most varied responses were recorded at the item B24 (variability coefficient 1.24) what means that the highest variety of the responses, as to the attractiveness (interest), was given by the respondents to the use of aggregate functions in queries for statistical, financial and economic data analysis. A higher variety of the responses was recorded also in case of the items B18 (variability coefficient 1.21), B17 (1.20) and B26 (1.20). On the basis of the mean interval estimation the average score values range from 2.80 to 3.00 (B18 - utilization of macros to automate repetitive operations in MS Excel), from 2.74 to 2.94 (B17 - numerical and graphical analysis of data through the pivot table and pivot chart), from 2.69 to 2.90 (B26 - dynamic interconnection of data between MS Access and external applications) regarding to the assessment of the attractiveness (interest) of the concerned issues by the respondents.

Average values of the respondents` answers to the items B1 - B26 (Table 5) are in the range from 2 (rather interesting) to 4 (rather uninteresting) at the maximal scale value 5 . The majority of the questionnaire items was assessed by the respondents as neither interesting, neither uninteresting (scale value 3 ). This is a quite alarming result, as in the context of the other results this proves that the students of the economy and managerial study programmes do not consider study of these informatics topics to be interesting enough. But this is only a hypothetical level. Exactness into this situation could be brought by testing the correlations between the given results and the respondents' assessments of the interest (attractiveness) or meaningfulness of the content of the particular learning topics included in the part What I would like to learn (items D1 - D22), assessed from 
the point of view of their future professional career. Further, the question is to which level, from the student point of view, the educational content of the concerned study subjects is fulfilled at the lessons.

Table 5 shows noticeable displacement move in the positive assessment of the items B6 and B7 in the seventh homogeneous group towards the items B1 and B3 in the first homogeneous group. Besides the fact, that at these items of the given two groups the highest means of the score were recorded $(B 6=3.90 ; B 7=$ 3.85 - rather interesting), or the lowest ones $(B 1=2.16 ; B 2=2.16$ - rather uninteresting), also the difference between the respondents' answers to these items is statistically significant. In this way the students declared their opinion that the use of tools and advanced techniques of work with MS PowerPoint to create interactive presentations (B6) and creating and formatting of structured documents using MS Word tools (B7), which are taught at informatics lessons, are interesting enough.

The third, and the biggest, identified homogeneous group is overlapping either with the second homogeneous group (B14, B16, B26, B17, B22, B4) or with the fourth one (B24, B19, B18, B23, B2, B25) on the level of all their items (with the exception of the item B21 at the second group). In a detailed look at the results of the assessments of the topics related to database systems and database technologies (items B19-B26) it is clear that all these items are part just of the mentioned second or third homogeneous group. Statistically significant difference of the respondents` answers was recorded e.g. between the assessments of the interest level of the topics defining relationship between database tables (B20) and work with large-scale data at maths, statistical or logical function applications (B12 - use of functions) and the data tools offered by the Microsoft Excel environment (B13 - work with large tables using data tools).

Statistically significant differences between the respondents` answers were recorded also in case of some relatively related topics, as are e.g. selection of required data using queries (B22) and filtering large tables, defining filter criteria for the values of different formats (B11), or using aggregate functions in queries for statistical, financial and economic data analysis (B24) and using the tools for analytical output creation (B16), as well as some other assessed topics which are integrated into the curricula of the subjects Informatics and Managerial informatics included in the first and second term of the study programmes carried out at the Faculty of Economics and Management at SPU in Nitra, or the subject Informatics for economists I/ included in the study programmes of the respondents studying at the Faculty of Business and Economics at MU in Brno.

To master a well-done database design is a rather challenging task for students, because it requires to have developed analytic thinking at an appropriate level - to create a conceptual scheme on the basis of information acquired about the concerned area, on the basis of this scheme to develop a logical model which undergoes a normalization process, and consequently to design a physical model of the database. To manage methodology of database designing requests knowledge of a lot of new terms, procedures, modelling approaches, normalization processes, etc. Object approach, in which the database designer, modelling a real situation, should be focused mainly on the categorization of the objects, which he is working with, into the appropriate categories and determination of the relations between these objects and relevant categories, is not easy, more to the contrary. Experiences with database system teaching prove that students have serious problems, when they get assignments to design a database, to define right entities, attributes, application rules and relations between the entities. It happens very often that they cannot differentiate between the entities and attributes, and defining the right relations between the data entities rather not to mention.

At the items B3 and B1 the research sample of the students expressed more in a negative way, giving their opinions to the theoretical informatics topics (number systems, transfer algorithms of numbers between systems) and algorithmization of mathematical problems solving interest (attractiveness). The mean of the score at these two items achieved significantly the lowest values (of the same value 2.16). Currently, in informatics teaching in the economy and managerial study programmes, lower and lower attention is paid to algorithmization. Algorithmization is mostly taught on a minimal level in the frame of informatics subjects incorporated in the general part of the study programmes. But, it is not infrequent to find algorithmization and programming included in the study programmes also as obligatory or optional self-existent subjects. This follows the fact that algorithmic thinking and algorithmic problem solution processes in connection to the current practice and labour market demands are becoming more and more important part of the informatics competency (literacy) required from the economy and managerial study programme graduates.

Students, who learn to inscribe the solved problems in the algorithm form, need to understand the learnt 
issues and to acquire correct and complex ideas on the used terms. Otherwise, they are not able to understand further ideas which follow from these ones, what causes that they are not able to apply them in any relevant practical tasks given to them. It is also important to call the students` attention to the fact, that theoretical informatics knowledge and algorithmization skills have a broad transfer except other areas also into the area of the data database processing by the means of the SQL language, or into the area of database application programming through script languages (e.g. PHP, Perl, Python or JavaScript). Through the optional subjects aimed at programming, included in the selected economy and managerial study programmes, the students have a possibility to obtain and develop their programming knowledge and algorithmization skills, and they can learn to apply them at solving more difficult tasks in an accessible advanced program language. Besides teaching programming carried out in the accessible advanced program language, also theoretical informatics topics used to be included in the curricula. In this area, teachers used to teach the theory of formal languages, grammars, automatics and operating systems. But, a program language mastery is currently becoming more and more sensitive need even for a common user as these skills are necessary to design own web sites, to set macros in documents, to design simple games or to design different applications for common own needs (Klement, 2000).

From the descriptive statistics presented in Table 6 it is clear that the values of the standard deviation of the respondents 'responses to the particular items do not vary markedly. From the point of view of this statistical indicator the most different responses were at items B19 (1.58), B20 (1.48), B21 (1.58), B22 (1.31) and B26 (1.42) in the group of the respondents - ACT study programme students. At the item B24 the highest variety (1.44) of the responses was recorded in the group representing EDP study programme. Within the used scale these results express assessments in the range from rather uninteresting learning topics to rather interesting learning topics.

The lowest value of the standard deviation, what means the lowest heterogeneity of the expressed answers (0.75), was recorded in the group of the respondents - BMA study programme students, at the item B22 (selection of required data using select query). The values of the particular answers vary from 2.50 up to 3.20 (see the confidence interval of the mean estimation). The next ones were the standard deviation value 0.80 (the confidence interval of the mean estimation in the range from 3.44 to 4.06) in the group of QME study programme students, item B24 (attractiveness/interest of the topic using aggregate functions in queries for statistical, financial and economic data analysis), and standard deviation value 0.83 (the confidence interval of the mean estimation in the range from 1.81 to 2.59) at the item B20 (attractiveness/interest of the topic defining the relationship between database tables), again in the group of the respondents specialized in BMA. The same results, i.e. the lowest divergences in the respondents answers', can be found at the items B21 (0.97) and B19 (1.03) in the group of QME students and at the item B26 (1.13) in the BEC group. In these study groups the respondents' answers just to the above-mentioned items show the lowest heterogeneity at the reached values of the confidence interval of the mean estimation from 3.38 to 4.12 for B21, 3.21 to 4.01 for B19 and 2.77 to 3.02 for B26.

Responses of the respondents studying in Slovakia to the items B19, B20, B21, B22, B24 and B26 were almost identical with those given by the respondents studying in the Czech Republic. The respondents evaluated the attractiveness and interest of the assessed learning topics as very neutral, i.e. mostly they stated that the given topic is neither interesting nor uninteresting for them. Processing the collected data in dependence on the factor GENDER, the subgroup of the respondents - boys marked the highest score at the item B24 (mean 2.98) and the group of girls at B19 (2.96). The lowest value of the standard deviation, what means the lowest heterogeneity of the answers, was recorded at the respondents - boys at the item B20 (1.06). The confidence interval of the mean estimation is in the range from 2.42 (what means assessment of the learning topic on the level rather uninteresting) up to the value 2.74 (what means assessment of the learning topic on the level neither interesting nor uninteresting). Relatively high homogeneity (1.07) in the respondent answers in relation to the attractiveness/interest of the particular learning topics was found out in the subgroup of the respondents girls at the item B22. The confidence interval of the mean estimation for this group has a range from 2.75 to 2.97 from the maximum scale value 5 .

On the basis of the dot mean estimation of the assessments of the particular learning topics regarding the area of database systems and database technologies, it can be stated that the respondents in Slovakia in 
comparison to those studying in the Czech Republic evaluated four from the six concerned items in a more positive way (B19, B21, B22, B26). Exceptions are the items B20 (level of the attractiveness/interest of the topic defining the relationship between database tables) and B24 (level of the attractiveness/interest of the topic using aggregate functions in queries for statistical, financial and economic data analysis). At the same time in the group of the Czech respondents the answers to the item B20 show the highest value of the standard deviation (1.44), what means the highest variability $(2.41-3.30)$ of the respondents` answers at their differentiation according to the COUNTRY factor.

Experiences and achievements connected with instruction of database and information technology curricula within the economy and management fields of study at the tertiary level (ISCED 6, ISCED 7) in the West European countries, USA and also in the Central European countries are described in many professional publications and studies (Gorgone, Gray, Stohr, Valacich, \& Wigand, 2006; Ekstrom \& Renshaw, 2003; Springsteel, Robbert \& Ricardo, 2000; Urban \& Dietrich 2001; Robbert, Wang, Guimaraes \& Myers, 2000). Their authors point out that the practice demand on higher education graduates specialized in economy or management is to dispose, except of the economical, managerial or marketing erudition, also of the adequate knowledge and skills from the area of database systems and information technologies. This knowledge and skills are very often the crucial criterion for the enterprise bodies at recruiting just the graduates of the mentioned specializations. Just the graduates familiar with the work with the database systems and technologies or with the data mining at the quantitative statistical method application are many times productive and successful in their professional career (Jakuš \& Páleníková, 2009).

As Drlík and Skalka indicate (Drlík \& Skalka, 2009), a possible solution could be the academic initiative Oracle Academy of the Oracle company and the possibilities to integrate it into the present curricula of different types of schools not only in Slovakia. The Oracle Academy initiative offers study programmes through which students and teachers have access to the most current software products, study materials and certificates in quite interesting reasonable prices (Oracle Academy, https://academy.oracle.com/).

\section{Conclusions}

The presented results can be understood as a kind of the current state of informatics teaching within the study programmes of economy and managerial specialization. But, what is more important, they create a platform showing the ways in which the informatics education of the students in the concerned study branches should be innovated and modernized to reach its proclaimed quality assurance and meet the demands of the student profilization according to the practice and labour market needs.

With regard to the possibilities of the economy and managerial study programme graduates to employ themselves in the labour market in the context of its current requirements on their professional competencies, it is indisputable that the issues of the database systems and database technologies should be included in the study programmes of their pre-graduate training. A question is the specification of the learning topics related to the database systems and database technology issues, which should be accentuated and which should be stated as inessential or supplementary for the specialization of the concerned study programme graduates. Another question is whether the relevant study specializations should have the same informatics preparation or whether the informatics training should be diversified in dependence on each specific specialization. In general the respondents stated the topics use of tools and advanced techniques of work with MS PowerPoint to create interactive presentations, use of tools and advanced techniques of work with MS PowerPoint to create interactive presentations, possibilities of conditional cell formatting in MS Excel, programming and web site design, programming of the web applications (chat, discussion forums, e-business) and harmful software (viruses, Trojan horse, spyware, adware, hoaxy) as the most significant from the point of view of their professional specialization. However, in the context of the presented findings, it can be discussed whether it is a consequence of the specific requirements of the professional specialization or rather a consequence of the need to develop the common key competencies of each information society member (Hašková, 2004). Skills to design effective interactive presentations in the MS PowerPoint environment, to create and format structured documents in MS Word applications are currently considered to be one of the basic key competencies, whereby as the key competencies are specified those which are applicable in solving wide scopes of usually unpredictable prob- 
TERTIARY ECINGMY AND MANAGERIAL STUdY FIELdS AND ISSUES GF SCIENCE EDUCATION AIMED ISSN $1648-3898$ AT DATABASE SYSTEMS

(P. 535-555)

lems, and enabling individuals to cope successfully with rapid changes in work, private and social life (Hrmo \& Turek, 2003; Šimonová, 2009).

\section{References}

Burgerová, J., Maněnová, M., \& Adamkovičová, M. (2013). New perspectives on communicaion and co-operation in e-learning. Praha: ExtraSYSTEM.

Drlík, M., \& Skalka, J. (2009). Sú databázové systémy len pre informatikov? [Are the database systems only for informatics?] Technológia vzdelávania: Technology of Education, 15 (2), 9-12.

EC (2001). European report on the quality of school education: Sixteen quality indicators. Luxembourg: Office for Official Publications of the European Communities.

ECDL. European Computer Driving Licence. Retrieved 18/03/2015, from http://www.ecdl.sk/testy-ecdl/sylaby-ecdl-advanced

Ekstrom, J., \& Renshaw, S. (2003). Database curriculum issues for four-year IT programs. In Conference for Industry and Education Collaboration (CIEC 2003). Tucson: Arizona.

Gorgone, J. T., Gray, P., Stohr, E. A., Valacich, J. S., \& Wigand, R. T. (2006). MSIS 2006: Model curriculum and guidelines for graduate degree programs in information systems. In Proceedings of the 2006 American Society for Engineering Education Annual Conference \& Exposition (ASEE 2006). Washington: American Society for Engineering Education.

Hašková, A. (2004). Digital literacy in new forms of education. In AGRIA MEDIA 2004: Digital Identity is the Passport to Europe, 60-66. Eger: EKF Líceum Kiadó.

Hrmo, R., \& Turek, I. (2003). Klúčové kompetencie I. [Key competencies I.]. Bratislava: Slovak University of Technology.

Jakuš, D., \& Páleníková, M. (2009). Záujem zamestnávatelov o absolventov VŠ. [Employers' interest in HEl graduates]. Bratislava: ARRA, Profesia.

Johnston, B., \&Webber, S. (2003). Information literacy in higher education: A review and case study. Studies in Higher Education, 28 (3), 335-352.

Jong, O. D. (2007). Trends in Western science curricula and science education. Journal of Baltic Science Education, 6 (1), $15-22$.

Klement, M. (2000). Výuka algoritmizace a programování v jazyce Visual Basic 5.0. [Teaching alghoritmization and programming in Visual Basic 5.0]. In Sborník přednášek z mezinárodní vědecko-odborné conference: Trendy technického vzdělávání [Proceedings of the international scientific conference: Trends in technical education]. 211-214. Olomouc: Pedagogická fakulta UP.

Lamanauskas, V. (2013). Natural science education importance in adolescence. Journal of Baltic Science Education, 12 (4), 396-398.

Lareki, A., Morentin, J. I. M., \& Amenabar, N. (2010). Towards an efficient training of university faculty on ICTs. Computers \& Education, 54 (2), 491-497.

MŠ. Sústava študijných odborov Slovenskej republiky vydaná rozhodnutím Ministerstva školstva Slovenskej republiky č. 2090/2002sekr. zo dňa 16. decembra 2002 v znení rozhodnutí Ministerstva školstva Slovenskej republiky (System of the study fields of the Slovak Republic approved by the Ministry of Education of the Slovak Republic No. 2090/2002-secr. on December $16^{\text {th }}$, 2002). Retrieved 18/02/2015, from http://www.akredkom.sk/index.pl?tmpl=odbory

OECD (2007a). PISA 2006 Science competencies for tomorrow's world. Volume 1: Analysis. Paris: OECD.

OECD (2007b). PISA 2006 Science competencies for tomorrow's world. Volume 2: Data. Paris: OECD.

OECD (2010a). PISA 2009 Results: Executive summary. Paris: OECD.

OECD (2010b). PISA 2009 Results: What Students Know and Can Do - Student Performance in Reading, Mathematics and Science. Vol. I. Paris: OECD.

OECD (2014). PISA 2012 Results: What Students Know and Can Do - Student Performance in Mathematics, Reading and Science. Vol. I. Paris: OECD Publishing.

OECD (2015). PISA 2015 Draft Science Framework. Retrieved 18/04/2015, from http://www.oecd.org/pisa/pisaproducts/ pisa2015draftframeworks.htm.

Oracle Academy. Software, Training, Resources and More. Retrieved 20/04/2015, from https://academy.oracle.com/

PAS. Prepojenie vzdelávania s potrebami trhu práce [Interconnection of education with the labour market needs]. Retrieved 29/04/2015, from http://www.alianciapas.sk.

Pešaković, D., Flogie, A., \& Aberšek, B. (2014). Development and evaluation of a competence-based teaching process for science and technology education. Journal of Baltic Science Education, 13 (5), 740-755.

Robbert, M. A., Wang, M., Guimaraes, M., \& Myers, M. (2000). The database course: What must be taugh. In Proceedings of 31 st SIGCSE Technical Symposium on Computer Science Education, 403-404. New York: ACM.

Skalka, J., Drlik, M., \& Švec, P. (2012). E-learning courses quality evaluation framework as part of quality assurance in higher education. In Interactive collaborative learning (ICL 2012). Villach: IEEE.

Springsteel, F., Robbert, M. A., \& Ricardo, C. (2000). The next decade of the database course: Three decades speak to the next. In Proceedings of 31st SIGCSE Technical Symposium on Computer Science Education. 41-45. New York: ACM.

Šebo, M. (2013). Support for non-technical education students through social networks. Edukacja - Technika - Informatyka: wybrane problemy edukacji informatycznej i informacyznej, 4 (2), 330-342. 
Šimonová, I. (2009). ICT in the process of instruction, a tool for developing managerial skills. In I. Šimonová, P. Poulová, M. Šabatová, \& et al., On contribution of modern technologies towards developing key competences, 111-115. Hradec Králové: Miloš Vognar Publishing House.

Urban, S. D., \& Dietrich, S. W (2001). Advanced Database Concepts for Undergraduates: Experience with Teaching a Second Course. In Proceedings of 32nd SIGCSE Technical Symposium on Computer Science Education. 357-361. New York: ACM.

Zúbková, M., \& Orosiová, K. (2011). Knowledge transfer from universities to practice. Nehnutel'nosti a bývanie [Real estates and housing], 6 (1), 36-48.

Received: June 20, 2015

Accepted: August 22, 2015

Ján Záhorec

Alena Hašková

Michal Munk

Martin Bílek
Professional Assistant, Methodology and Pedagogy Centre in Bratislava, Slovak Republic, Ševčenkova 11, 85005 Bratislava, Detached workstations MPC, UI. kozmonautov 5, 94901 Nitra, Slovak Republic;

Department of Informatics, Faculty of Economics and Management, Slovak University of Agriculture in Nitra,

Tr. A. Hlinku 2, 94976 Nitra, Slovak Republic.

E-mail: jan.zahorec@mpc-edu.sk

Website: http:// www.mpc-edu.sk

Professor, Department of Technology and Information Technologies, Faculty of Education, Constantine the Philosopher University in Nitra,

Dražovská cesta 4, 94974 Nitra, Slovak Republic.

E-mail:ahaskova@ukf.sk

Website: http://www.ukf.sk

Associate Professor, Department of Informatics, Faculty of Natural Sciences, Constantine the Philosopher University in Nitra, Tr. A. Hlinku 1, 94974 Nitra, Slovak Republic.

E-mail:mmunk@ukf.sk

Website: http://www.ukf.sk

Professor, Department of Chemistry, Faculty of Science, University of Hradec

Králové, Rokitanského 62, 50003 Hradec Králové, Czech Republic.

E-mail: martin.bilek@uhk.cz

Website: http://www.uhk.cz 